\title{
e-Migrinter
}

$5 \mid 2010$

Migrations dans les pays nordiques

\section{Integration and transnational practices of Filipinos in Iceland}

\section{Unnur Dís Skaptadóttir}

\section{(2) OpenEdition \\ Journals}

Electronic version

URL: https://journals.openedition.org/e-migrinter/2041

DOI: 10.4000/e-migrinter.2041

ISSN: 1961-9685

Publisher

UMR 7301 - Migrinter

\section{Printed version}

Date of publication: 28 April 2010

Number of pages: $35-46$

ISSN: 1961-9685

\section{Electronic reference}

Unnur Dís Skaptadóttir, "Integration and transnational practices of Filipinos in Iceland", e-Migrinter

[Online], 5 | 2010, Online since 20 April 2020, connection on 20 May 2021. URL: http://

journals.openedition.org/e-migrinter/2041 ; DOI: https://doi.org/10.4000/e-migrinter.2041

Tous droits réservés 


\title{
Integration and transnational practices of Filipinos in Iceland
}

\author{
Unnur Dís Skaptadóttir
}

$\mathbf{I}^{\prime}$

melda is a fifty year old woman who moved to Iceland in the early 1990s. In the Philippines, she was a widow with three children having a difficult time making ends meet. She had a cousin living in Iceland who told her that she could arrange for her to come to work there, so Imelda left her children with her sister and mother and got a job in a rural Icelandic fish plant; she lived sparingly and sent what was left of her wages back to her family in the Philippines.

\section{Introduction}

Within one year Imelda met an Icelandic man. He was older than her but had never been married before. Shortly after their marriage, Imelda and her new husband decided to bring the children to Iceland to live with them. Imelda has also actively been helping other people, mostly relatives (both men and women), find employment so that they can come to Iceland and live. She is happy with her life in Iceland, works in elderly care, has a husband who has become a father to her children, and she has built a network of relatives around her. She travels to the Philippines to visit now and then but makes the trip less often now that her parents have passed away and many of her close relatives have joined her in Iceland.

Imelda is one of the many people who have moved to Iceland in the last twenty years as a result of an economic boom that created a demand for a large number of workers in production, services and construction. In this article, I examine immigration in Iceland throughout the past two decades and focus specifically on the experiences of people who have moved from the Philippines. I pay particular attention to people's daily life experiences as well as how these relate to processes of inclusion and exclusion, integration and transnational practices. My study shows that categorizing these people as either labor migrants or immigrants is not an easy task. I examine work and family life in order to illustrate how transnational activities and integration processes are not easily distinguished in these two spheres. To improve one's life and that of the family is one of the primary reasons for moving to Iceland, because migrants are capable of earning wages in Iceland that are much 
higher than those in their country of origin. However, many extend their stay and have important family networks within Iceland. Both work and family life are thus directly linked to the transnational social field as well as participation in a new society. Immigrants' work must be put in a global context and in the context of existing immigration rules in the society receiving them.

The diverse aspects of transnational experiences have been studied in recent years, especially with regard to transnational family life, economic remittances and political or cultural involvement in the country of origin Basch et al. 1994; Vertovec 1999; Guarnizo et al. 2003; Landholt 2001; Parrenas 2001). While focusing on mobility and cross-border activities, researchers have also been concerned with how a life lived in two or more places impacts person's identity and sense of belonging to a particular place (Wimmer and Glick-Schiller 2003). Vertovec, for example, in discussing the lives of migrants, points out that "many migrants today intensively conduct activities and maintain substantial commitments that link them with significant others (such as kin, covillagers, political comrades, fellow members of religious groups) who dwell in nationstates other than those in which the migrants themselves reside" (Vertovec 2004: 970971). Amongst individual migrants living transnational lives this entails the emergence of a dual orientation or bifocality in everyday life. Bifocality, Vertovec says, is something that cannot easily be measured "but its workings are clearly discernable in social practices and conveyed in individual narratives" (ibid.: 977); these practices have considerable impact on "individual and family life course and strategies, individuals' sense of self and collective belonging, the ordering of personal and group memories, patterns of consumption, collective sociocultural practices, and approaches to childrearing and other modes of cultural reproduction" (Vertovec 2004: 977). Now, as never before, he argues, migrants can sustain and act upon a strong sense of connection with people, places and a sense of belonging that is associated with their place of origin (Vertovec 2004).

Levitt and Glick-Schiller argue that our analytical lens must broaden and deepen because individuals are embedded in multilayered, multi-sited transnational social fields, encompassing those who move and those who stay behind (Levitt and GlickShiller 2004: 3). The economy of many households in poorer countries relies to a large extent on the mobility of its members. Sørensen and Olwig call this type of migration mobile livelihoods and they promote "shifting the analytical focus from place to mobility, and from 'place of origin' and 'place of destination' to the movements involved in sustaining a livelihood" (Sørensen and Olwig 2002: 2). The state and the economy of the Philippines benefits from remittances from abroad and it is thus important to keep the ties with those who have moved away. Migration from the Philippines is extensive, and it has been maintained this export of labor from the Philippines has been one of the country's major economic development strategies to fight unemployment and earn foreign currency since the 1970s (Semyonov and Gorodzeisky 2005). In 2003, the Filipino government decided to allow dual citizenship for those who had decided to change their citizenship while living abroad. Those who lobbied for this change used the economic argument that allowing dual citizenship would encourage people to keep their ties to the Philippines and use their money there (Glick-Shiller 2005).

These kinds of global and transnational perspectives, which have raised questions of belonging vs. participation, have helped uncover the complexity of integration into a multicultural society. Eriksen (2007) points out that people who see themselves as belonging to the same ethnic group can be integrated in different ways socially and culturally. One can, for 
example, be a participant in a labor market and pay taxes in a society without knowing the language or the cultural heritages of the dominant ethnic group. Moreover people belonging to minority groups may feel that their interests are not necessarily best served by cultural integration into the nation state. They may find it more beneficial to utilize transnational networks (2007:1062). As Eriksen also points out that inclusion and exclusion, chosen or enforced, have to be taken into account, but these are often difficult to distinguish in real life. He maintains that we need to ask "which forms of exclusion are practiced in greater society, and which are the requirements for inclusion" (Eriksen 2007: 1060). Is inclusion or exclusion exercised on the basis of perceived cultural difference, language abilities or social aspects with regard to, for example, work or housing? By using these concepts the emphasis is then not only on the agency of the immigrants but also that of the receiving society as well.

A question that needs to be raised in this context is: what does integration entail? How much does an immigrant have to change to prove his or her integration, and in which areas of life? How much diversity is the nation state willing to tolerate within its borders, and how are the cultural borders of the nation state defined? Grillo (2007) demonstrates that the meaning of the concepts of integration and multiculturalism may differ and is not always clear to people. Moreover, are the perceptions of the authorities or of the immigrants more important in our evaluations of integration? In other words: for whom is 'integration'? Theorizing about the inner dynamics and power differences within ethnic and national groups, such as those based on gender, age and class, is the dominant trend in current research. For example what is immigrants' position in the labor market, and are they excluded from particular aspects of it? What role does family play in this regard?
These topics are addressed in this article about the integration and transnational practices of Filipinos in Iceland. The data on which this article is based is derived from a larger ethnographic study that includes interviews with men and women living in the capital city area of Iceland as well as in smaller villages in other parts of the country. The participants in the study are of different backgrounds and have moved to Iceland from various islands of the Philippines since 1990.

\section{The Icelandic context of migration}

Twenty years ago only few people living in Iceland had foreign citizenship or were born abroad. Since then, there has been a large increase in immigrations. In 1996 immigrants constituted $2 \%$ of the Icelandic population (defined as born abroad with both parents born abroad). In 2004 immigrants make up $4 \%$ of the population, and $8.1 \%$ in 2008 (Garðarsdóttir, Hauksson and Tryggvadóttir 2009). Today, $75 \%$ if them come from Europe; Poles are by far the largest national group with $30 \%$ of the total number of immigrants in Iceland. About $15 \%$ of all immigrants in Iceland come from various Asian countries, mostly comes from the Philippines (Statistics Iceland 2009).

Work has been the main reason for migration to Iceland, although family reunification and studying are also important. Economic transformations with growing privatization and increased deregulations from the 1990s resulted in an economic boom and consequently in a labor shortage in the country (Skaptadóttir 2004a; 2004b; 2009). In the beginning, people were mostly needed for jobs in fish processing plants but were soon also in demand for various jobs in the service sector, such as cleaning and care. These jobs are considered to be those of women, so there was originally a higher demand for femaie (Skaptadóttir and Wojtynska 2008). After 2000 , with the construction of a large power 
plant, an aluminum smelter and a number of new buildings in the capital area, men began to arrive in greater numbers so that women were no longer the majority of foreign citizens in the country in 2004. Many workers stayed only temporarily and did not renew their work permits, and some construction laborers worked for foreign subcontractors only on particular job assignments. A large majority of the people who have been moving to Iceland in recent years can thus be said to be labor migrants. This is reflected by the fact that in 2007, 9\% of the work force in Iceland had foreign citizenship and most migrants fell in the age range from 19 to 39 years old. Meanwhile, children with foreign citizenship account for merely $2 \%$ of all children and the percentage of elderly people with foreign citizenship is a little lower (Iceland Statistics, 2009).

Unlike other North European countries there are very few refugees in Iceland and only 510 individuals have been accepted as quota refugees into the country since $1956 \quad$ (Félags- og tryggingamálaráðuneytið 2009). Until 2003 the largest groups of people who came to Iceland on the basis of such temporary workpermits were from Poland, the Philippines and Thailand. The temporary permits, which had to be renewed yearly, were held by the employer. After three years of working for the same employer, the employee was able to apply for a permanent work permit. Since 2004 people from the European Union and the European Economic Area have been given priority on the labor market, and since 2006 they are no longer required to apply for a work permit in Iceland. They have the right to seek labor for three months after entering the country. People from countries outside Europe still nead a work permit before entering the country, and this has become particularly difficult to obtain many have in fact settled in Iceland.
Work life

A Filipino woman in her late twenties, who had completed an education as an economist, got a job in fish processing through a friend and arrived in Iceland in 2000. After three years in a rural fish plant, she received a permanent work and residence permit and got a job in a restaurant. She shares an apartment with a few friends of her from the Philippines. She has taken Icelandic courses, but since she has not worked with Icelanders in either of her work places she has not had much of an opportunity to speak the language. In spite of not being able to use her education, she talked about how lucky she is to work in Iceland compared to her possibilities in the Philippines; she said she was glad to be able to send money back to her parents and siblings. After eight years in Iceland, she says she has not yet decided how long she will stay in Iceland, but she is hoping to be able to move to an English speaking country in the future.

The migration from the Philippines began with a few Filipino women moving to Iceland to marry Icelandic men in the 1980s and early 1990s. Thus they were the first to arrive, and some of them have become key players in the migration chain that has followed. The population of Filipinos grew slowly in the 1990s, but in the last decade the number of native born Filipinos living in Iceland has tripled (Statistics Iceland 2009). As with other migrant groups, most of the people who have moved to Iceland from the Philippines were in their twenties or thieties and there have been more women than men. However, although the number of men has increased in recent years (as in other migrant groups), women are still twice as numerous as men in all age groups except for that under the age of 19 (Statistics Iceland 2009).

Incorporation into the labor market is often emphasized in discussions of migrants' integration into a new society (Alba and Nee 1997; Esser 2004). Most of the people from 
the Philippines, as with others who have moved to Iceland in the last two decades, began working right after arriving in the country. Thus they were active participants in economic activities from the beginning, which among other things entailed the paying of taxes and inclusion in labor unions. This is also the case for many who have come to Iceland on the grounds of family reunification since their relatives commonly helped find employment for them and took care of all the paper work (in cooperation with employers) before they arrived. As with other nationalities, employment in fish processing plants was frequently the first job for those who came in the 1990s, and in many cases the fish plants were located in small, fishery-based villages in rural areas. Some of the people interviewed in my study still work in the fish plants whereas others have moved on to other jobs (e.g. in other food production, other manual labor, and other services). For women, care work is common mostly in institutions but also to some degree in private homes. Since child care is easily available live-in housemaids are very rare in Iceland. Despite difficult working conditions, and the fact that many Filipinos are employed in jobs unrelated to their education and training, many talk about being lucky to get a job in Iceland. At the same time, they also talk about what it is like to do jobs that they would never have found acceptable to do in the Philippines. Many of them were raised in middle class homes and were supported in their education by parents or other relatives working abroad.

The Filipinos in Iceland are a very diverse group; they, for instance, have different educational backgrounds and a wide range of work experience before arriving. Many of those who participated in my study have university degrees in business, nursing, engineering, hotel management and other disciplines. Only few of them have been able to make use of their education and most have not attempted to do so. They justify this by explaining that their Icelandic is not good enough or that they are not interested in pursuing employment in their original fields of study since their work in Iceland is only temporary. With the exception of nurses, who have been able to pursue their careers only after fulfilling the health care sector's criteria, many Filipinos do not have employment corresponding to their level of education.

Knowledge of the local language has been seen as important for integration in Iceland. Icelandic is a crucial aspect of what it means to be an Icelander. Icelandic as key to participation, and to gaining knowledge of Icelandic society and culture, is clearly stipulated in the Integration policy of the government that was first released by the government in 2007. People from the Philippines, as with other migrants, often only work with other foreigners or work alone in cleaning jobs. As a result, many of them do not have much of a chance to learn Icelandic in the working place. It is usually not until after they have been working in Iceland for some period of time that they find out about the language courses that are available. Many participants have taken courses in Icelandic, and they have been involved in different courses to improve their position on the labor market. Because they are non-European citizens, they are required to take a minimum of 150 hours of Icelandic language courses before being able to apply for residence permits and/or permanent work permits. In spite of the fact that the state does not provide Icelandic courses and people have to pay for them, an Icelandic test has since the beginning of this year become a requirement for applying for citizenship. Having a job in care work gives more opportunities to communicate with Icelanders and learn the language. Many of those interviewed said that it was not until they began to work with the elderly or in a kindergarten that they finally began to speak the language (Skaptadóttir 2007).

Language is, however, not as much of a hurdle as it is for some of the other 
migrants since most of the Filipinos speak English. They can thus communicate with their English-speaking coworkers and managers in the work place. This has given them access to society that many people from Poland and Thailand do not have. Knowing English means that they can get to know people at work and elsewhere and more readily familiarize themselves with new circumstances. As a matter of fact, many of them describe positive experiences from work and constructive relations with managers. They tell stories of managers that have helped them when they were in need (i.e. when they have had to travel with short notice to the Philippines on account of sickness or a death in the family). However, even though speaking English is an esset, the participants in my study plan to stay in Iceland and many have children in school and thus want to learn Icelandic for the purpose of broader communication in society.

Insufficient knowledge of Icelandic, for example, means that one has to be dependent on others to translate information that arrives by mail from authorities or service providers. Such information is often in an official, bureaucratic language that is difficult to understand. In some cases this has led to misunderstandings of rights and duties with regard to union participation, taxes and workers' wage slips. Letters from authorities, institutions or employers are commonly translated by relatives and friends. Among the Filipinos, some individual women, who have lived in Iceland for a long time (and sometimes their Icelandic husbands), play a larger role in this and distribution of information.

New laws came into effect in 2004, and these laws gave priority to Europeans on the Icelandic labor market; this affected the Filipinos greatly. According to current laws, it is only possible to hire people from countries outside Europe if it is not possible to find the person to do the job within
Iceland, the European Union or the European Economic Area (Directorate of labor 2009). Filipinos can also no longer help arrange for their relatives to come and work in Iceland (e.g. their children over 18 years of age, spouse, cousins or siblings). Many of the participants in my study found this very frustrating. During the interviews that were conducted, many were preoccupied with this issue and some described the effort involved in trying to get their relatives to come and stay with them in Iceland.

As already mentioned, most of the people from the Philippines, as well as migrants from other countries in Iceland, are of working age. These migrants are working for higher wages than those available to them in the Philippines, and this has been a major reason for many to come to Iceland. Because of the high value of the Icelandic currency, a job in Iceland was seen as being economically beneficial. Some of them had only stayed temporarily and them returned to the Philippines, but the majority has settled in Iceland. Most of the participants in the study have someone they support in the Philippines, and most of them say that they came to Iceland in order to help their families. Almost all the participants send money to their parents, siblings, children or other relatives. The money is used to invest in housing, health services, medications, and to previde for the education of the children. With the economic collapse, and the collapse of the value of the Icelandic currency, it has become difficult to send as much money back to relatives.

\section{Family life}

"I am all alone," a woman in her thirties kept telling me. She had lived in Iceland for almost a decade. She has an Icelandic husband and two children and many Icelandic and Filipino friends. She added, however, that she is not as alone now as she was during the first few years before she met her husband. A Filipino man, the 
same age as she, feels otherwise. He is married to a woman from the Philippines whom he met after his aunt arranged employment for him in Iceland. He pointed out in an interview that one of the main reasons why he is happy is that he has such a large kin group in Iceland. $\mathrm{He}$ sends remittances to his parents in the Philippines. They have visited him but found Iceland too cold and desolate to even considering moving to live near him.

The family life of the Filipinos living in Iceland transcends national borders. They are connected, although to a different degree, with relatives in the Philippines and in other countries. They assist their families by giving them part of the wages they earn in Iceland. They maintain daily contact through Skype and MSN, and this technology allows people to participate in the day-to-day activities of the family left behind. The internet is used for other things as well (i.e. for watching television programs), but most people say that they use it primarily to stay in touch with relatives. A few people mentioned that they had even bought a computer for a relative in order to better maintain communication. Some people are planning to or have already bought an apartment or a house in the Philippines for the money they have earned in Iceland. They commonly have some relative living in the houses they have invested in and part of the money is sent to pay for the upkeep of the property. Because of the long and expensive trip, people do not travel back and forth between the two places often, but when they do travel there they stay for a longer period of time. It is important for them to see the family, especially to see sick parents or to attend weddings or funerals and to bring their children to meet relatives.

The extent of transnational activity observed in my studies consists mostly of these kinds of traveling back and forth and keeping in touch with friends and relatives in what most people refer to as home country.
Some people talk about belonging in different ways to both places, others say that they participate in one society and belong to another. Places however, continue to be vital, both their former and current homes. The meanings of these places are nevertheless continuously negotiated in different contexts. Very few Filipinos in Iceland have plans to return in the near future. About half of those born in the Philippines and living in Iceland have Icelandic citizenship (Statistics Iceland 2009). Most of those who do not have Icelandic citizenship have not lived in Iceland for seven years, and do not yet have the right to apply for citizenship.

It was very clear that having relatives from the Philippines living nearby was very important for the well-being of those who participated in my study. Spending time with relatives and seeking help from them is very important for the participants in the study. Many of them belong to a large kinship group in Iceland. They help each other with practical issues relating to housing and work, and they also heal each other with papers that have to be filled out and submitted. They socialize, eat Filipino food together, exchange films, and sing karaoke. They also have large gatherings for special occasions like Christmas. When people compared the difference between the two countries, they pointed out that family ties were much more important among Filipinos than Icelanders. The importance ascribed to helping each other out among grown up siblings, when the siblings are both living in Iceland as well as when the siblings live in separate countries, was commonly given as evidence of this. Helping is also extended to nieces and nephews. Thus some of the interviewees send money for the college education of their nieces or nephews and would like to help them move to Iceland or elsewhere where they can get a good job. Many talked about feeling better in Iceland because they had relatives living in Iceland as well. Some of those who, on the contrary, did not have relatives in Iceland talked about the lack of 
assistance available to them from other Filipinos when in need. Those who have family in Iceland are more interested in settling, learning the language, and are more likely to consider using their education than those who do not have relatives in Iceland.

Marriage between an Icelandic man and a woman from the Philippines is common but the opposite is very unusual. Men born in the Philippines are in most cases married to women from the Philippines. Women with an Icelandic husband have a different story than those who come on their own or to reunite with family members. Filipino women married to Icelandic men come to stay in Iceland and become part of an Icelandic family thus learning the different aspects of Icelandic society more quickly. In many cases their inlaws help them get better jobs than they might otherwise have gotten. Having an Icelandic spouse is also like having a Filipino family network and is important for well being and interest in participation. Although a few of the women who participated in the study have been unfortunate in their marriages with Icelandic men, most of the women who are married to Icelandic men talk about positive aspects e.g. support in many aspects of life and dealing with the society and getting new network of relatives through him. They also appreciate the acceptance of their children from former marriages. In most cases, the husband takes care of most of the practical issues in dealing with authorities. This is seen as a positive aspect, although for those few who did not have a good marriage, this was a source of even more dependence and distress when divorcing.

\section{Discussion and conclusion}

In this article, I have focused on transnational activities and integration processes through an examination of peoples' experiences of work and family life. Work and family reunification are the main reasons for the migration of Filipinos to
Iceland. Like other first generation migrants, people from the Philippines emphasize maintaining contact with relatives in their country of origin. However they are simultaneously busy participating in a new society. Although only few can use their education or former work experience, they are working for wages higher than available in country of origin and this gives them a better chance to provide for relatives by sending remittances; until recently, this also enabled them to help others find employment and come to Iceland to work. They compare the two places repeatedly and keep what Vertovec calls a bifocal view.

Although the majority of those moving to Iceland from the Philippines are of a working age, it is not an easy task to categorize them as simply migrant laborers or as immigrants. Many of them come both to work and to be with relatives. It is thus clear from my study that those who participated did not only migrate in order to begin new lives for themselves, but just as much to improve the lives of their families back home (Sørensen and Olwig 2002). Migrants from the Philippines have been active in the labor market. However, in spite of their knowledge of English and the fact that many speak Icelandic, they are mostly in low paid jobs where their education is not utilized. Many have good relations with coworkers and, primarily as a result of their knowledge of English, they get to know the society faster than many other migrant groups. Processes of inclusion and exclusion are often not easily discerned as they have to do with limitations in the jobs available to them. Exclusion processes are more formally visible in the rules that prioritize people from the European Union and the European Economic Area thus making it almost impossible for people from other parts of the world trying to access the Icelandic labor market. To belong to a family network gives access to some aspects of society and, moreover, it makes people more satisfied and happy about living in Iceland even though they may have varying 
knowledge of Icelandic culture and traditions; some have their kin networks from the Philippines, others gain knowledge through an Icelandic spouse, and yet others have both. An Icelandic family network can open up new opportunities for jobs and participation. Regardless, in both cases having a family network makes people more interested in participating, in learning the language and taking on new jobs where they are more likely to utilize their education.

Because of the strong perceptions of immigrants as temporary workers in Iceland, it has been assumed that people will return to their country of origin when there are fewer jobs to be had. People from the Philippines are however not leaving. While maintaining ties with relatives in the Philippines many of them have become citizens and have settled with a family. By focusing on both transnational ties and integration processes simultaneously we can see that one does not exclude the other. They are clearly participants in two societies in terms of social and economic integration. How familiar they are with local culture and traditions however varies.

Unnur Dís Skaptadóttir University of Iceland Professor of anthropology unnurd@hi.is

\section{Bibliography}

Alba, Richard ; Nee, Victor (1997) Rethinking Assimilation Theory for a New Era of Immigration, International Migration Review, 31(4), pp. 26-74.

Eriksen, Thomas H. (2007) Complexity in social and cultural integration: some analytical dimensions, Ethnic and Racial Studies, 30(6), pp. 1055-1069.

Esser, Hartmut (2004) Does the "New" Immigration Require a "New" Theory of Intergenerational Integration?, International Migration Review, 38(3), pp. 1126-1159.

Félags- og tryggingamálaráðuneytið (2009) disponible sur internet: $<$ http://www.felagsmalaraduneyti.is/malafl okkar/flottafolk/mottaka/nr/1228>

Garðarsdóttir, Ólöf ; Hauksson, Guðjón ; Tryggvadóttir, Helga Katrín (2009) Innflytjendur og einstaklingar með erlendan bakgrunn 1996-2008, Hagtídindi, n¹.

Glick Shiller, Nina (2005) Long-Distance Nationalism, in Ember, Melvin ; Ember, Carol R. ; Skoggard, Ian, Encyclopedia of Diasporas. Immigrant and Refugee Cultures Around the World, New York, Springer, pp. $570-580$

Grillo, Ralph (2007) An excess of alterity? Debating difference in a multicultural society, Ethnic and Racial Studies, 30(6), pp. 979-998.

Guarnizo, Luis E. ; Portes, Alejandro ; Haller, William (2003) Assimilation and Transnationalism: Determinants of Transnational Political Action among Contemporary Migrants, American Journal of Sociology, 180(6), pp. 1211-1248.

Gupta, Akhil ; Ferguson, James (eds.) (1997) Culture, Power, Place: Exploration in Critical Anthropology, Durham and London, Duke University Press, $361 \mathrm{p}$.

Levitt, Peggy ; Glick Schiller, Nina (2004) Conceptualizing Simultaneity: A Transnational Social Field Perspective on Society, International Migration Review, 38(3), pp. 1002-1039. 
Olwig, Karen F. ; Sørensen, Ninna N. (eds.) (2002) Work and migration: Life and Liveliboods in a Globalizing World, London, Routledge, $240 \mathrm{p}$.

Parreñas, Rhacel S. (2001) Servants of Globalization: Women, Migration, and Domestic Work, Stanford, Stanford University Press, $309 \mathrm{p}$.

Semyonov, Moshe ; Gorodzeisky, Anastasia (2005) Labor Migration, Remittances and Household Income: A Comparison between Filipino and Filipina Overseas Workers, International Migration Review, 39(1), pp. 45-68.

Skaptadóttir, Unnur D. (2004a) Responses to Global Transformations: Gender and Ethnicity in Resource-based Localities in Iceland, Polar Record, 40, pp. 261-267.

- (2004b) Mobilities and Cultural Difference: Immigrants' Experiences in Iceland, in Ingimundarson Valur, Loftsdóttir, Kristín and Erlingsdóttir Irma (eds.), Topographies of Globalization: Politics, Culture, Language, Reykjavík: University of Iceland press, pp. 133-148.

Skaptadóttir, Unnur D. (2007) Ólíkar raddir: Afstaða innflytjenda til íslensks máls, Ritið 1, pp. 45-61.

Skaptadóttir, Unnur D. ; Wojtynska, Anna (2008) Gender Migration from Poland to Iceland. Women's Experiences in Golańska, Dorota ; Różalska, Aleksandra M. (eds), New Subjectivities: Negotiating Citizenship in the Context of Migration and Diversity, Lodz, University of Lodz Publishing House, pp. 81-96.
Skaptadóttir, Unnur D. ; Loftsdóttir, Kristín (2009) Cultivating Culture? Images of Iceland, Globalization and Multicultural society, in Jakobsson, Sverrir (ed.), Images of the North, Studia Imagoloica 14, Amsterdam, Rodopi, pp. 205-216.

Statistics Iceland (2009) Mannfjöldi, Ríkisfang, fæðingarland og uppruni íbúa, disponible sur internet: $<$ http://www.statice.is/Statistics/Populatio n/Citizenship-and-country-of-birth>

Sørensen, Ninna N. ; Olwig, Karen S. (2002) Mobile Livelihoods. Making a Living in the World, in Olwig K. og N. Sørensen (eds.), Work and migration, London, Routledge, pp. 1-20.

Vertovec, Steven (1999) Conceiving and Researching Transnationalism, Ethnic and Racial Studies, 22(2), pp. 447-462.

- (2004) Migrant Transnationalism and Modes of Transformation, International Migration Review, 38(3), pp. 970-1001.

Wimmer, Andreas ; Glick-Schiller, Nina (2003) Methodological nationalism, the social sciences and the study of migration. An essay in historical epistemology, International Migration Review, 37(3), pp. 576-610. 